\title{
Selective Hydrodeoxygenation of Alkyl Lactates to Alkyl Propionates with Fe-based Bimetallic Supported Catalysts
}

Khokarale, Santosh Govind; He, Jian; Schill, Leonhard; Yang, Song; Riisager, Anders;

Saravanamurugan, Shunmugavel

Published in:

ChemSusChem (Print)

Link to article, DOI:

10.1002/cssc.201702411

Publication date:

2018

Document Version

Peer reviewed version

Link back to DTU Orbit

Citation $(A P A)$ :

Khokarale, S. G., He, J., Schill, L., Yang, S., Riisager, A., \& Saravanamurugan, S. (2018). Selective Hydrodeoxygenation of Alkyl Lactates to Alkyl Propionates with Fe-based Bimetallic Supported Catalysts. ChemSusChem (Print), 11(4), 681-687. https://doi.org/10.1002/cssc.201702411

\section{General rights}

Copyright and moral rights for the publications made accessible in the public portal are retained by the authors and/or other copyright owners and it is a condition of accessing publications that users recognise and abide by the legal requirements associated with these rights.

- Users may download and print one copy of any publication from the public portal for the purpose of private study or research.

- You may not further distribute the material or use it for any profit-making activity or commercial gain

- You may freely distribute the URL identifying the publication in the public portal 


\section{CHEMISTRY \& SUSTAINABILITY

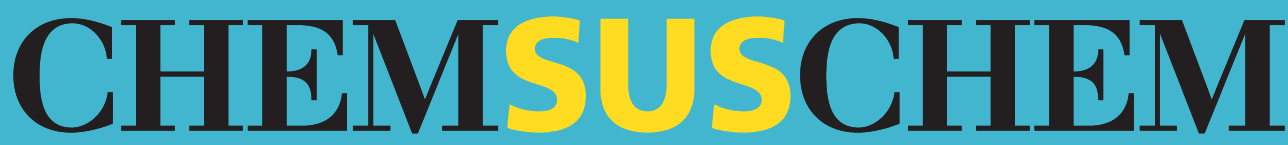

ENERGY \& MATERIALS

\section{Accepted Article}

Title: Selective Hydrodeoxygenation of Alkyl Lactates to Alkyl Propionates with Fe-based Bimetallic Supported Catalysts

Authors: Santosh Govind Khokarale, Jian He, Leonhard Schill, Song Yang, Anders Riisager, and Saravanamurugan Shunmugavel

This manuscript has been accepted after peer review and appears as an Accepted Article online prior to editing, proofing, and formal publication of the final Version of Record (VoR). This work is currently citable by using the Digital Object Identifier (DOI) given below. The VoR will be published online in Early View as soon as possible and may be different to this Accepted Article as a result of editing. Readers should obtain the VoR from the journal website shown below when it is published to ensure accuracy of information. The authors are responsible for the content of this Accepted Article.

To be cited as: ChemSusChem 10.1002/cssc.201702411

Link to VoR: http://dx.doi.org/10.1002/cssc.201702411 


\title{
Selective Hydrodeoxygenation of Alkyl Lactates to Alkyl Propionates with Fe-based Bimetallic Supported Catalysts
}

\author{
Santosh Govind Khokarale, ${ }^{[a]}$ Jian He, ${ }^{[a b]}$ Leonhard Schill, ${ }^{[a]}$ Song Yang, ${ }^{[b]}$ Anders Riisager, ${ }^{[a] *}$ and \\ Shunmugavel Saravanamurugan ${ }^{[a c] *}$
}

\begin{abstract}
Hydrodeoxygenation (HDO) of methyl lactate $(\mathrm{ML})$ to methyl propionate (MP) were performed with various base metal supported catalysts. A high yield of $77 \%$ MP was obtained with bimetallic $\mathrm{Fe}-\mathrm{Ni} / \mathrm{ZrO}_{2}$ in methanol at $220{ }^{\circ} \mathrm{C}$ at 50 bar $\mathrm{H}_{2}$. A synergic effect of $\mathrm{Ni}$ increased the yield of MP significantly when using $\mathrm{Fe}-\mathrm{Ni} / \mathrm{ZrO}_{2}$ instead of $\mathrm{Fe} / \mathrm{ZrO}_{2}$ alone. Moreover, the $\mathrm{ZrO}$ support contributed to improve the yield as a phase transition of $\mathrm{ZrO}_{2}$ from tetragonal to monoclinic occurred after metal doping giving rise to fine dispersion of the $\mathrm{Fe}$ and $\mathrm{Ni}$ on the $\mathrm{ZrO}_{2}$, implying the higher catalytic activity of the material. Intriguingly, it was observed that $\mathrm{Fe}-\mathrm{Ni} / \mathrm{ZrO}_{2}$ also effectively catalyzed methanol reforming to produce in situ $\mathrm{H}_{2}$, followed by $\mathrm{HDO}$ of $\mathrm{ML}$, yielding $60 \% \mathrm{MP}$ at $220{ }^{\circ} \mathrm{C}$ with 50 bar $\mathrm{N}_{2}$ instead of $\mathrm{H}_{2}$. Fe$\mathrm{Ni} / \mathrm{ZrO}_{2}$ also catalyzed $\mathrm{HDO}$ of other short chain alkyl lactates to the corresponding alkyl propionates in high yields around $70 \%$. No loss of activity of $\mathrm{Fe}-\mathrm{Ni} / \mathrm{ZrO}_{2}$ occurred in five consecutive reaction runs demonstrating the high durability of the catalyst system.
\end{abstract}

\section{Introduction}

The demand for fossil-based resources are continuously increasing as the need for commodity chemicals, fuels and energy ascend along with a growing world population [1]. Concomitantly, the limited availability of fossil resources will steadily be diminishing in the coming decades, striving industries

[a] Dr. S. G. Khokarale, Dr. L. Schill, J. He, Prof. A. Riisager Dr. S. Saravanamurugan

Centre for Catalysis and Sustainable Chemistry, Department of Chemistry, Technical University of Denmark

DK-2800 Kgs. Lyngby, Denmark

E-mail: ar@kemi.dtu.dk

[b] J. He, Prof. S. Yang

State-Local Joint Engineering Lab for Comprehensive Utilisation of Biomass, Center for R\&D of Fine Chemicals, Guizhou University, Guiyang, Guizhou 550025, China

[c] Dr. S. Saravanamurugan

Laboratory of Bioproduct Chemistry, Center of Innovative and Applied Bioprocessing (CIAB), Mohali 140 306, Punjab, India E-mail: saravana@ciab.res.in

Supporting information for this article is given via a link at the end of the document. and academia to find alternative renewable resources that potentially can replace fossil-based chemicals and fuels [2]. In this connection, terrestrial biomass - in particular the lignocellulosic fraction - has been identified as a renewable, abundant carbon-neutral resource for making chemicals and fuels [3]. However, the direct transformation of lignocellulosic component to targeted chemicals, such as cellulose to lactic acid, is generally tedious and challenging [4]. Conversions of cellulosic sugar-derived platform chemicals to commodity chemicals seems more promising and feasible, as this allow us to improve the yield and selectivity of the targeted products [5].

Lactic acid is a bio-platform chemical derived from glucose, which can be produced by well-established fermentative or alternative chemo-catalytic processes [6]. Lactic acid is an important feedstock to make biodegradable plastics, but can also serve as a feedstock for producing precursors (e.g., methyl propionate, MP) for existing large-volume acrylic plastics, e.g. poly(methyl methacrylate), PMMA. Currently, MP is preferentially made for PMMA production in industry by methoxycarbonylation of ethylene with carbon monoxide in methanol using a Pd-phosphine based homogeneous catalyst in a batch process [7]. The major drawbacks of this process are cautious handling of reactant (e.g., poisonous $\mathrm{CO}$ gas, expensive metal complex, reactive phosphine ligand) as well as tedious catalyst recovery and recycling.

Hydrodeoxygenation (HDO) is one of the important transformations to reduce the oxygen content by cleaving $\mathrm{C}-\mathrm{O}$ bonds with hydrogen to produce value-added chemicals from bio-based substrates [8]. It has been widely studied with regard to hydrogenolysis of polyols to corresponding partly or fully deoxygenated product with a wide range of solid catalyst including base metals such as $\mathrm{Ni}$ and $\mathrm{Co}$ [9]. In connection with this, hydrogenolysis of $\alpha$-hydroxy acids/esters to propylene glycol, 1-propanol and propionic acid/ester have also been reported [10]. Here propylene glycol was predominantly formed with $\mathrm{Ru}, \mathrm{Pd}, \mathrm{Ni}, \mathrm{Cu}$ on various supports such as carbon, $\mathrm{TiO}_{2}$, alumina and silica, and no selective hydrogenolysis of lactic acid or its ester(s) toward propionic acid or its esters were achieved. Hence, only up to $23 \%$ product selectivity of propionic acid was attained at $74 \%$ conversion of lactic acid with $10 \mathrm{wt} \% \mathrm{Cu} / \mathrm{SiO}_{2}$ [10e]. The reaction selectivity towards ethyl propionate improved to $66 \%$ when replacing $\mathrm{Cu}$ with $\mathrm{Co}$ and $\mathrm{Fe}$ in the catalyst, but with very poor conversion of ethyl lactate (9\%) [11]. These previous studies inspired us to search for base metal-containing 
catalysts, which selectively can hydrodeoxygenate alkyl lactates to alkyl propionates in respective alcohols. Especially, inexpensive $\mathrm{Ni}$ and $\mathrm{Fe}$ metals and $\mathrm{ZrO}_{2}$ as support have some advantageous properties in terms of activity and stability during the reaction. $\mathrm{Ni} / \mathrm{SiO}_{2}$ has previously been reported to efficiently hydrogenate furfural to furfuryl alcohol, whereas Fe-containing $\mathrm{Ni}$ catalysts favoured $\mathrm{C}-\mathrm{O}$ cleavage by hydrogenolysis to form methyl furan [12a]. Similarly, Ni on carbon nanotubes (CNT) exhibited good reactivity for converting 5-hydroxymethylfurfural to 2,5-furandimethanol (FDM). Concurrently, Ni-Fe/CNT favoured the formation of 2,5-dimethylfuran instead of FDM [12b]. Moreover, it is recognized that $\mathrm{Ni}$ has the ability to dissociate hydrogen easily for hydrogenation/hydrogenolysis reactions [12c]. On the other hand, applying $\mathrm{ZrO}_{2}$ as support has several advantageous due to its amphoteric and redox properties as well as its high thermal and hydrolytic stability [12eg]. These viewpoints encouraged us to explore the activity of base metals, including $\mathrm{Fe}-\mathrm{Ni}$ on $\mathrm{ZrO}_{2}$, for $\mathrm{HDO}$ of alkyl lactate to alkyl propionate.



Scheme 1. HDO of alkyl lactate to alkyl propionate in alcohol

Here, we report a selective and effective HDO reaction with base metal supported catalysts for converting alkyl lactates to the corresponding alkyl propionates in high yields in alcohols (Scheme 1). A maximum yield of $77 \%$ MP was obtained from methyl lactate $(\mathrm{ML})$ using $\mathrm{Fe}-\mathrm{Ni} / \mathrm{ZrO}_{2}$ catalyst. A phase transition of zirconia was confirmed by XRD analysis after incorporation of $\mathrm{Fe}$ and $\mathrm{Ni}$ metals, suggesting that the metals were incorporated well into the zirconia network thereby possibly enhancing the activity of the material. Notably, a good yield of MP (60\%) was also obtained from ML without added hydrogen gas, implying that hydrogen can be generated from methanol reforming with $\mathrm{Fe}-\mathrm{Ni} / \mathrm{ZrO}_{2}$. Other parameters like e.g., influence of metal content, reaction temperature and time, concentration of $\mathrm{ML}$, and the recyclability of $\mathrm{Fe}-\mathrm{Ni} / \mathrm{ZrO}_{2}$ have also been explored.

\section{Results and Discussion}

\section{Preliminary studies with precious metals}

Catalyst screening for the transformation of ML to MP with $\mathrm{Ru}$ or $\mathrm{Re}$ on activated carbon (Ru/AC or $\mathrm{Re} / \mathrm{AC}$ ) at $200^{\circ} \mathrm{C}$ at 50 bar $\mathrm{H}_{2}$ resulted in poor yield of 7 and $3 \%$, respectively, with low conversion of ML (around 10\%). However, previous work suggest that the presence of Re in combination with other metals, including $\mathrm{Ru}$, can promote the yield for similar HDO reactions [13]. In line with this, the yield of MP enhanced significantly from
7 to $20 \%$ with bimetallic $\mathrm{Ru}-\mathrm{Re} / \mathrm{AC}$ catalyst and to $32 \%$ when using reduced $\mathrm{Ru}-\mathrm{Re} / \mathrm{AC}$ catalyst at $220^{\circ} \mathrm{C}$ (Table S1). In order to improve the MP yield further catalysts based on common oxide supports (e.g., $\mathrm{TiO}_{2}, \mathrm{SiO}_{2}, \mathrm{Al}_{2} \mathrm{O}_{3}$ and $\mathrm{ZrO}_{2}$ ) were examined and the results are presented in Table $\mathrm{S} 1$. $\mathrm{Ru}-\mathrm{Re} / \mathrm{SiO}_{2}, \mathrm{Ru}$ $\mathrm{Re} / \mathrm{Al}_{2} \mathrm{O}_{3}$ and $\mathrm{Ru}-\mathrm{Re} / \mathrm{ZrO}_{2}$ gave here comparable MP yield, but since $\mathrm{ZrO}_{2}$ is more stable than the other oxides [12g] it was chosen as preferred support to study alternative precious metals for the HDO reaction of ML to MP.

Various $\mathrm{ZrO}_{2}$-supported catalysts with precious metals (Rh, Ag, $\mathrm{Au}, \mathrm{Ir}, \mathrm{Pd}$ and $\mathrm{Pt}$ ) in combination with Re were tested for the conversion ML to MP, and the results are compiled in Table S2 and XRD patterns of the materials shown in Figures S1 and S2. Among the employed catalysts, $\mathrm{Au}-\mathrm{Re} / \mathrm{ZrO}_{2}$ and $\mathrm{Ir}-\mathrm{Re} / \mathrm{ZrO}_{2}$ proved particularly active yielding 54 and $46 \%$ of MP, respectively, while the other catalysts yielded between $20-40 \%$ of MP. These interesting results prompted us to substitute the precious metals in the $\mathrm{ZrO}_{2}$ catalysts with much cheaper and readily available base metals like $\mathrm{Fe}, \mathrm{Mo}, \mathrm{Mn}, \mathrm{Ni}, \mathrm{Co}, \mathrm{Cu}, \mathrm{Zn}$, and $\mathrm{Ni}$. The good to excellent HDO results obtained with these catalysts are compiled in Table 1, and the corresponding XRD patterns of the materials are given in Figure S3.

Table 1. HDO of ML to MP with bimetallic catalysts ${ }^{a}$

\begin{tabular}{llccccc}
\hline Entry & Catalyst & $\begin{array}{c}\mathrm{ML} \\
\mathrm{Conv} \\
(\%)\end{array}$ & $\begin{array}{c}\mathrm{MP} \\
\text { Yield } \\
(\%)\end{array}$ & $\begin{array}{c}\text { MMP } \\
\text { Yield } \\
(\%)\end{array}$ & $\begin{array}{c}\text { n-PrOH } \\
\text { Yield } \\
(\%)\end{array}$ & $\begin{array}{c}\text { Carbon } \\
\text { balance } \\
(\%)\end{array}$ \\
\hline 1 & $\mathrm{Ru}-\mathrm{Re} / \mathrm{ZrO}_{2}$ & 86 & 30 & 7 & 1 & 52 \\
2 & $\mathrm{Fe}-\mathrm{Re} / \mathrm{ZrO}_{2}$ & $>99$ & 60 & $<0.5$ & 10 & 70 \\
3 & $\mathrm{Fe}-\mathrm{Mn} / \mathrm{ZrO}_{2}$ & 88 & 33 & 3 & 0 & 48 \\
4 & $\mathrm{Fe}-\mathrm{Cu} / \mathrm{ZrO}_{2}$ & $>99$ & 36 & $<0.5$ & 0 & 36 \\
5 & $\mathrm{Fe}-\mathrm{Zn} / \mathrm{ZrO}_{2}$ & 74 & 40 & 8 & 0 & 74 \\
6 & $\mathrm{Fe}-\mathrm{Mo} / \mathrm{ZrO}_{2}$ & $>99$ & 47 & $<0.5$ & 0 & 47 \\
7 & $\mathrm{Fe}-\mathrm{Co} / \mathrm{ZrO}_{2}$ & $>99$ & 71 & $<0.5$ & 3 & 74 \\
8 & $\mathrm{Fe}-\mathrm{Ni} / \mathrm{ZrO}_{2}$ & $>99$ & 73 & 2 & 0 & 75 \\
9 & $\mathrm{Fe}-\mathrm{Ni}_{2} / \mathrm{ZrO}_{2}{ }^{\mathrm{b}}$ & 87 & 64 & 6 & 0 & 83 \\
10 & $\mathrm{Fe} / \mathrm{ZrO}_{2}{ }^{\mathrm{c}}$ & 85 & 45 & 2 & 0 & 62 \\
11 & $\mathrm{Ni}^{2} / \mathrm{ZrO}_{2}{ }^{\mathrm{c}}$ & 34 & 4 & 28 & 0 & 98 \\
12 & $\mathrm{Nano} \mathrm{Fe}_{2} \mathrm{O}_{3}$ & 44 & 13 & 1 & 0 & 70 \\
13 & $\mathrm{ZrO}_{2}$ & 32 & 0 & 22 & 0 & 90
\end{tabular}

a Reaction conditions: $2 \mathrm{mmol} \mathrm{ML}, 100 \mathrm{mg}$ catalyst (M/Re or $\mathrm{Fe} / \mathrm{M}=2 ; 3.6$ mol\% with respect to $\mathrm{ML}$ ), $8 \mathrm{~g} \mathrm{MeOH}, 50$ bar $\mathrm{H}_{2}, 12 \mathrm{~h}, 220 \stackrel{\circ}{\circ} \mathrm{C}$. ${ }^{b}$ Non-reduced. c $2.4 \mathrm{~mol} \%$ of $\mathrm{Fe}$ or $\mathrm{Ni}$ with respect to $\mathrm{ML}$.

\section{Study with nonprecious metal on the yield of MP}

Replacing $\mathrm{Ru}$ in $\mathrm{Ru}-\mathrm{Re} / \mathrm{ZrO}_{2}$ with the Group 8 analog $\mathrm{Fe}$ to obtain $\mathrm{Fe}-\mathrm{Re} / \mathrm{ZrO}_{2}$, the yield of MP substantially increased from 30 to $60 \%$ at quantitative conversion of ML (Table 1, Entries 1 and 2). In order to assess the role of $\mathrm{Fe}$ alone, an experiment was also performed with $\mathrm{Fe} / \mathrm{ZrO}_{2}$ which yielded $45 \%$ of $\mathrm{MP}$ (Table 1, Entry 10), i.e. 15\% higher than what was obtained with bimetallic $\mathrm{Ru}-\mathrm{Re} / \mathrm{ZrO}_{2}$. When replacing Re with the lighter Group 7 metal $\mathrm{Mn}$ in $\mathrm{Fe}-\mathrm{Mn} / \mathrm{ZrO}_{2}$, an adverse effect was observed as 
WILEY-VCH

the yield of MP descended from 60 to $33 \%$ (Table 1, Entry 3) confirming that $\mathrm{Mn}$ demoted the activity of $\mathrm{Fe} / \mathrm{ZrO}{ }_{2}$. Other identified by-products such as methyl 2-methoxypropanoate (MMP) and n-propanol were also quantified to account for the carbon balance (Table 1) and the plausible reaction pathway is shown in Scheme 2. Moreover, gas samples collected after the reactions were subjected to GC-MS analysis and showed the formation of $\mathrm{CO}_{2}$ and propane $(\mathrm{m} / \mathrm{z}$ of 44$)$, revealing that decarboxylation of methyl propionate (or propionic acid) and complete hydrogenation of methyl lactate took place, respectively. This could account for the rest of the carbon balance to some extent.

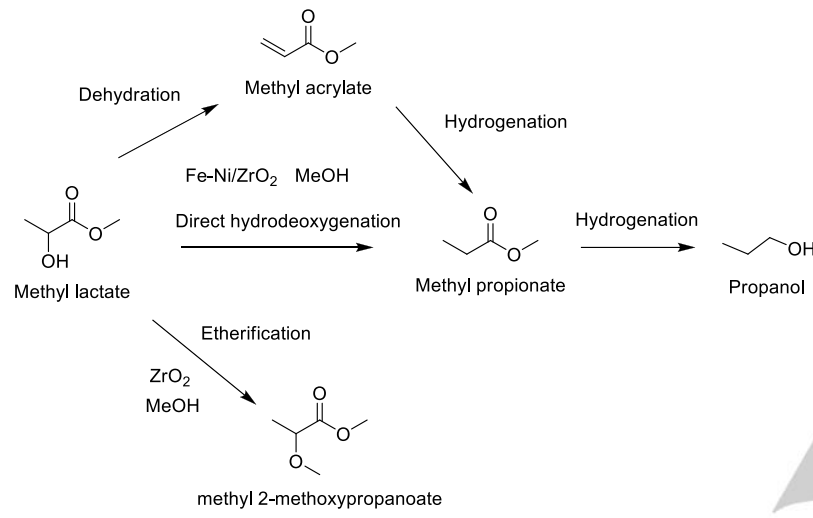

Scheme 2. Plausible reaction pathway for the conversion of ML with Fe$\mathrm{Ni} / \mathrm{ZrO}_{2}$.

The catalytic effect of other base metals ( $\mathrm{Zn}, \mathrm{Co}, \mathrm{Ni}, \mathrm{Mo}$, and $\mathrm{Cu}$ ) in place of $\mathrm{Re}$ in $\mathrm{Fe}-\mathrm{Re} / \mathrm{ZrO} 2$ was also investigated (Table 1). Among the catalysts studied, $\mathrm{Fe}-\mathrm{Ni} / \mathrm{ZrO} 2$ gave the highest yield of $73 \% \mathrm{MP}$ at full ML conversion (Table 1, Entry 8). Notably, when the support was altered to $\mathrm{SiO}_{2}, \mathrm{Al}_{2} \mathrm{O}_{3}, \mathrm{TiO}_{2}$, spinel or $\mathrm{AC}$ only poor to moderate yields of $3-47 \%$ MP was obtained (Table S3) indicating a synergistic activity effect of the $\mathrm{ZrO}_{2}$ support for Fe-Ni. In addition, methyl acrylate (MA) was also used as substrate to probe its reactivity if formed as an intermediate during the reaction. Here, $\mathrm{Ni} / \mathrm{ZrO}_{2}$ gave a higher yield of $\mathrm{MP}$ $(71 \%)$ whereas $\mathrm{Fe} / \mathrm{ZrO}_{2}$ and $\mathrm{ZrO}_{2}$ alone yielded 52 and $49 \%$, respectively. This clearly indicated that $\mathrm{Ni}$ favored hydrogenation compared to $\mathrm{Fe}$ leading to the speculation that $\mathrm{Fe} / \mathrm{ZrO}_{2}$ partly promoted the dehydration of $M L$ to form $M A$ followed by hydrogenation on $\mathrm{Ni}$ to form MP. Fe/ZrO $, \mathrm{Ni} / \mathrm{ZrO}_{2}, \mathrm{Fe}-\mathrm{Ni} / \mathrm{ZrO}_{2}$ and $\mathrm{ZrO}_{2}$ were by $\mathrm{NH}_{3}$-TPD analysis found to have available acid sites of $0.498-0.627 \mathrm{mmol} / \mathrm{g}$ with the former possessing about $20 \%$ more acid sites than $\mathrm{Ni} / \mathrm{ZrO}_{2}$ (Table S4). Moreover, $\mathrm{Fe} / \mathrm{ZrO}_{2}$ revealed a slightly higher $\mathrm{T}_{\max }\left(200^{\circ} \mathrm{C}\right)$ compared to $\mathrm{Ni} / \mathrm{ZrO}_{2}(160$ ${ }^{\circ} \mathrm{C}$ ) (Figure S4), indicating that $\mathrm{Fe} / \mathrm{ZrO}_{2}$ possessed slightly stronger acid sites which could facilitate the dehydration of $\mathrm{ML}$ to MA (Scheme 2).

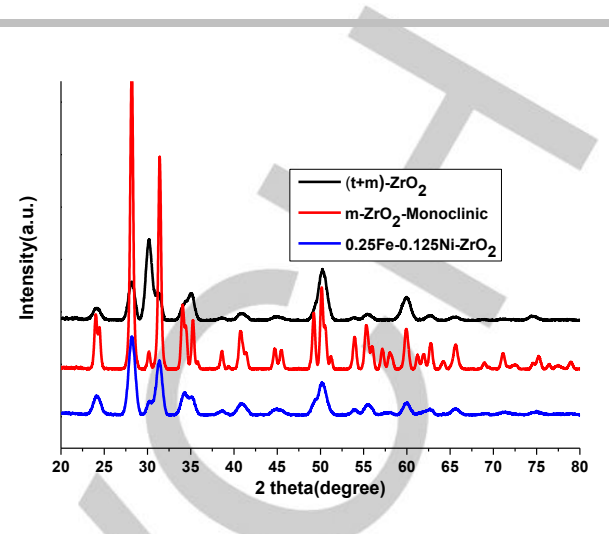

Figure 1. XRD patterns of $\mathrm{ZrO}_{2}$ and $\mathrm{Fe}-\mathrm{Ni} / \mathrm{ZrO}_{2}(2.7 \mathrm{wt} \% \mathrm{Fe}$ and $1.4 \mathrm{wt} \% \mathrm{Ni})$.

To get insight into the promoting role of $\mathrm{ZrO}_{2}$, the support and the $\mathrm{Fe}-\mathrm{Ni} / \mathrm{ZrO}_{2}$ catalyst were subjected to XRD analysis and part of the measured diffractograms are shown in Figure 1. $\mathrm{ZrO}_{2}$ derived from $\mathrm{Zr}(\mathrm{OH})_{4}$ showed an intense diffraction peak at $2 \theta$ of $30.2^{\circ}$ corresponding to (111) of the tetragonal phase along with two minor peaks at $2 \theta$ of 28.2 and $31.4^{\circ}$ ascribed to (11-1) and (111) of the monoclinic phase [14]. To ascertain formation of the monoclinic phase, $\mathrm{ZrO}_{2}$ was treated at $900 \stackrel{\circ}{\circ} \mathrm{C}$ and the XRD pattern of the resulting sample clearly indicated increased intensity of the 28.2 and $31.4^{\circ}$ peaks at the expense of the peak at $30.2^{\circ}$ from the tetragonal phase. A similar XRD pattern was apparently seen for the $\mathrm{Fe}-\mathrm{Ni} / \mathrm{ZrO}_{2}$ catalyst, substantiating that the two metals were well dispersed into the network of $\mathrm{ZrO}_{2}$ transforming the support predominantly to the monoclinic phase (Figure 1 and Table S5) as in accordance with previous report [15], which possibly contributed to the superior catalyst activity observed in the HDO reaction of ML. Moreover, no clear or distinct peak corresponding to metallic $\mathrm{Fe}$ or $\mathrm{Ni}$, FeNi alloy or mono- or mixed metal oxides were observed in the XRD patterns as those peaks might also have been overlapped with support $\mathrm{ZrO}_{2}$ if formed [16,12b,17]. In line with this, TEM analysis revealed formation of small particles with sizes around $2 \mathrm{~nm}$ for $\mathrm{Fe}-\mathrm{Ni} / \mathrm{ZrO}_{2}$ as well as for the $\mathrm{Fe}-\mathrm{Mn} / \mathrm{ZrO}{ }_{2}, \mathrm{Ir}-\mathrm{Re} / \mathrm{ZrO} \mathrm{O}_{2}$ and Pt$\mathrm{Re} / \mathrm{ZrO}_{2}$ catalysts (Figure S5). In contrast, no particles were visualized for the active $\mathrm{Au}-\mathrm{Re} / \mathrm{ZrO}_{2}$ and $\mathrm{Fe}-\mathrm{Co} / \mathrm{ZrO} \mathrm{r}_{2}$ catalysts, indicating that the size of the particles was less important for obtaining the synergic role of the $\mathrm{Fe}$ and $\mathrm{Ni}$ on $\mathrm{ZrO}_{2}$. Furthermore, the $\mathrm{Fe}-\mathrm{Ni} / \mathrm{ZrO}_{2}$ catalyst with $\mathrm{Fe} / \mathrm{Ni}$ ratio of 2 was subjected to XPS analysis before and after the HDO of ML to MP (Table S6). Before the reaction, the existing oxidation states of surface $\mathrm{Fe}$ and $\mathrm{Ni}$ were $\mathrm{Fe}^{2+}(68 \%) / \mathrm{Fe}^{3+}(32 \%)$ and $\mathrm{Ni}^{2+}(25 \%) / \mathrm{Ni}^{3+}(75 \%)$, respectively [18]. After reaction, the distribution of oxidation states for Fe remained unchanged, while no reliable results were obtained for $\mathrm{Ni}$ due to lack of surface $\mathrm{Ni}$ on the $\mathrm{ZrO}_{2}$. This confirmed that no metallic $\mathrm{Fe}$ and $\mathrm{Ni}$ were present on the $\mathrm{ZrO}_{2}$ surface, but did not rule out presence of metallic species in the interior part of the support. 


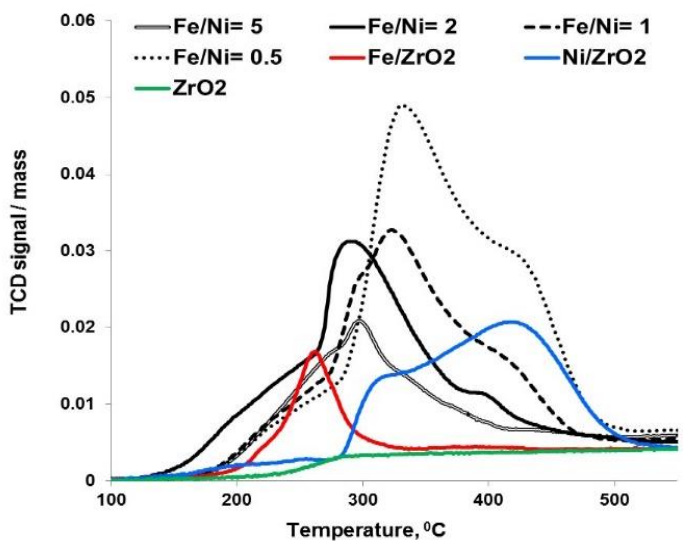

Figure 2. $\mathrm{H}_{2}$-TPR profile of $\mathrm{Fe}$ and/or Ni containing $\mathrm{ZrO}_{2}$ materials.

The reducibility of the catalysts was evaluated by temperature programmed reduction (TPR) with hydrogen and the results correlated with catalytic activity. Figure 2 shows $\mathrm{H}_{2}$-TPR profiles of the $\mathrm{Ni}$ - and/or Fe-containing $\mathrm{ZrO}_{2}$ catalysts. $\mathrm{Ni} / \mathrm{ZrO}_{2}$ (yielding only 4\% MP from ML) revealed a very broad profile with reduction peaks at $\mathrm{T}_{\max }$ of 310 and $420{ }^{\circ} \mathrm{C}$ assigned to the reduction of $\mathrm{NiO}$ and support interacting $\mathrm{NiO}$, respectively, to metallic $\mathrm{Ni}$ [19]. On the other hand, a distinct sharp peak appeared at $\mathrm{T}_{\max }$ of $266{ }^{\circ} \mathrm{C}$ for $\mathrm{Fe} / \mathrm{ZrO}_{2}$ (yielding $45 \% \mathrm{MP}$ from $\mathrm{ML}$ ) corresponding to the reduction of $\mathrm{Fe}_{2} \mathrm{O}_{3}$ to $\mathrm{Fe}_{3} \mathrm{O}_{4}$ in line with previous reports [20]. For the bimetallic $\mathrm{Fe}-\mathrm{Ni} / \mathrm{ZrO}_{2}$ catalysts reductions occurred already at around $150{ }^{\circ} \mathrm{C}$ and a major peak appeared between the $\mathrm{T}_{\max }$ of $\mathrm{Fe} / \mathrm{ZrO}_{2}$ and $\mathrm{Ni} / \mathrm{ZrO}_{2}$ depending on the catalyst composition. An analogous $\mathrm{Ni}$-induced lowering of the reduction temperature of iron oxides was seen for $\mathrm{Fe}$ $\mathrm{Ni} / \mathrm{SiO}_{2}$ (Fischer-Tropsch catalyst), implying that $\mathrm{Ni}$ facilitated hydrogen activation [21]. A similar observation was also found for $\mathrm{Fe}-\mathrm{Ni} / \mathrm{TiO}_{2}$ resulting in enhanced catalytic activity for synthesis gas conversion compared to $\mathrm{Fe} / \mathrm{TiO}_{2}$ [22]. The marked shift in reduction temperature in the present study suggests that more isolated oxide species had formed which were easily reduced at low temperatures, thus inferring a concerted effect of $\mathrm{Ni}$ in $\mathrm{Fe} / \mathrm{ZrO}_{2}$ on the yield of MP (73\%). Furthermore, $\mathrm{H}_{2}$ consumption was drastically reduced in the high temperature region above $400{ }^{\circ} \mathrm{C}$ compared to $\mathrm{Ni} / \mathrm{ZrO}_{2}$, revealing the formation of isolated and low temperature reducible species that also partly could contribute to the enhanced catalytic activity.

\section{Influence of reaction time, temperature and $\mathrm{Fe}$ to $\mathrm{Ni}$ ratio}

The catalytic activity of $\mathrm{Fe}-\mathrm{Ni} / \mathrm{ZrO}_{2}$ catalysts with $\mathrm{Fe} / \mathrm{Ni}$ mole ratios from $0.5-25$ was investigated after optimizing the reaction temperature and time (Figure 3 ) and the obtained results are summarized in Table 2. The corresponding XRD patterns of the catalysts are presented in Figure S6. The highest yield of $77 \%$ MP was obtained with the catalyst having a Fe/Ni mole ratio of 1 , when using a total metal loading of $4.9 \mathrm{~mol} \%$ with respect to
ML. Interestingly, when decreasing the $\mathrm{Ni}$ content five-fold relative to $\mathrm{Fe}$ (i.e. Fe/Ni ratio of 5 ) the yield of MP (72-73\%) was almost maintained no matter if the Fe loading was kept or doubled, manifesting that small amount of $\mathrm{Ni}$ was adequate to promote MP formation and demonstrating the importance of optimizing both the metal ratio and the metal loading towards maximizing the MP yield. XPS analysis of the $\mathrm{Fe}-\mathrm{Ni} / \mathrm{ZrO}_{2}$ catalysts with the various $\mathrm{Fe} / \mathrm{Ni}$ ratios (Table S6) further revealed that the contribution of $\mathrm{Ni}^{2+}$, but not $\mathrm{Fe}^{2+}$, significantly descended as the $\mathrm{Fe} / \mathrm{Ni}$ ratio in the catalyst increased while the yield of MP decreased. Moreover, it can be inferred that the catalyst with a $\mathrm{Fe} / \mathrm{Ni}$ ratio of 1 possessed the highest relative amount of $\mathrm{Ni}^{2+}$, which could be easily reduced and contribute during reaction to obtain the highest MP yield (77\%) among the employed catalysts. According to the TPR results and previous relevant reports, $\mathrm{Ni}$ can accelerate the reduction of iron oxide by activating hydrogen $[21,22]$, thus suggesting a synergetic role between $\mathrm{Ni}$ and Fe for activating hydrogen and the HDO reaction of $\mathrm{ML}$ to MP, respectively. When the concentration of ML was increased from 2.5 to $6.1 \mathrm{wt} \%$ (i.e. 2 to $5 \mathrm{mmol} \mathrm{ML}$ ) the MP yield descended from 73 to $41 \%$ whereas the selectivity remained almost similar. The initial high yield could however be obtained at prolonged reaction time of $24 \mathrm{~h}$ (Table S7).
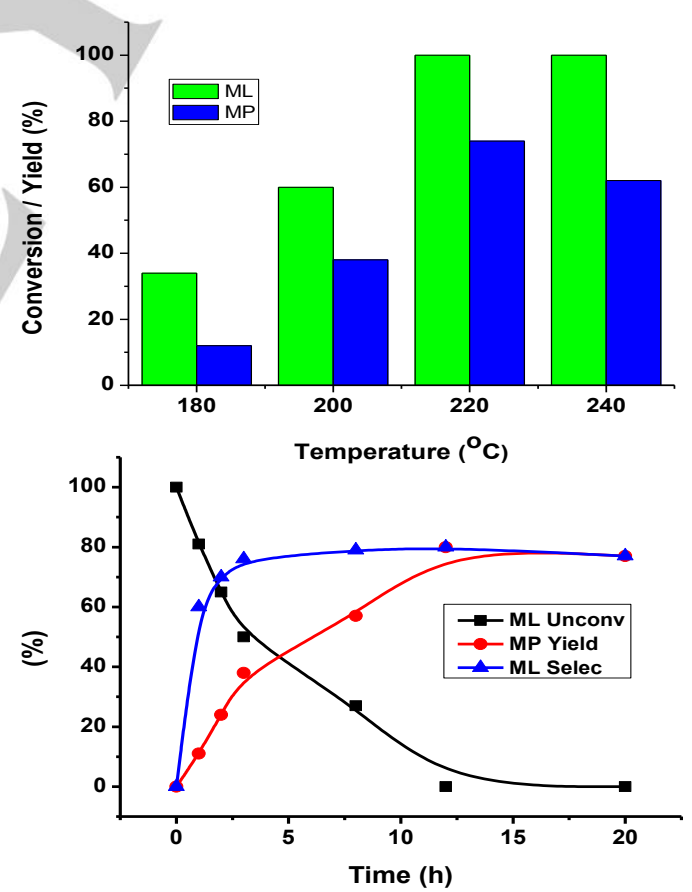

Figure 3. The influence of reaction temperature (top) and time (bottom) on the yield of MP. Reaction conditions: $2.0 \mathrm{mmol} \mathrm{ML}, 100 \mathrm{mg}$ catalyst $(\mathrm{Fe} / \mathrm{Ni}=2,3.6$ mol\% with respect to $\mathrm{ML}$ ), $8 \mathrm{~g} \mathrm{MeOH}, 50$ bar $\mathrm{H}_{2}$. Catalysts activated at $450{ }^{\circ} \mathrm{C}$ in static air followed by reduction at $300{ }^{\circ} \mathrm{C}$ for $3 \mathrm{~h}$ under formier gas flow (10 vol. \% $\mathrm{H}_{2}$ in $\left.\mathrm{N}_{2}, 50 \mathrm{ml} / \mathrm{min}\right)$. 
Table 2. The influence of metal composition of $\mathrm{Fe}-\mathrm{Ni} / \mathrm{ZrO}_{2}$ on the yield of $\mathrm{MP}^{\mathrm{a}}$

\begin{tabular}{lllllllll}
\hline Entry & $\begin{array}{l}\text { Catalyst } \\
\mathrm{Fe}-\mathrm{Ni} / \mathrm{ZrO}_{2}\end{array}$ & $\begin{array}{l}\mathrm{Fe} / \mathrm{Ni} \\
\text { ratio }\end{array}$ & $\begin{array}{l}\text { mole } \\
(\mathrm{mol} \%)^{\mathrm{b}}\end{array}$ & $\begin{array}{l}\mathrm{Fe} \text { content } \\
(\mathrm{mol} \%)^{\mathrm{b}}\end{array}$ & $\begin{array}{l}\text { content } \\
(\%)\end{array}$ & $\begin{array}{l}\text { Conv. } \\
(\%)\end{array}$ & $\begin{array}{l}\text { Yield } \\
(\%)\end{array}$ \\
\hline 1 & $\mathrm{Fe}_{1} \mathrm{Ni}_{2}$ & 0.5 & 2.44 & 4.76 & $>99$ & 67 & 77 & 73 \\
3 & $\mathrm{Fe}_{1} \mathrm{Ni}_{1}$ & 1 & 2.44 & 2.44 & $>99$ & $>99$ & 71 \\
4 & $\mathrm{Fe}_{1} \mathrm{Ni}_{0.5}$ & 2 & 2.44 & 1.23 & $>99$ & 72 \\
5 & $\mathrm{Fe}_{1} \mathrm{Ni}_{0.4}$ & 2.5 & 2.44 & 0.01 & $>99$ & 78 & 73 \\
6 & $\mathrm{Fe}_{1} \mathrm{Ni}_{0.2}$ & 5 & 2.44 & 0.58 & $>99$ & 26 \\
\hline
\end{tabular}

${ }^{a}$ Reaction conditions: $100 \mathrm{mg}$ catalyst, $2.0 \mathrm{mmol} \mathrm{ML}, 8 \mathrm{~g} \mathrm{MeOH}, 50$ bar $\mathrm{H}_{2}, 12 \mathrm{~h} .{ }^{\mathrm{b}} \mathrm{Mol} \%$ with respect to $\mathrm{ML}$. Catalyst activated at $450{ }^{\circ} \mathrm{C}$ in air followed by reduction at $300^{\circ} \mathrm{C}$ for $3 \mathrm{~h}$ under formier gas flow (10 vol. \% $\mathrm{H}_{2}$ in $\mathrm{N}_{2}, 50 \mathrm{ml} / \mathrm{min}$ ).

\section{Influence of partial pressure of $\mathrm{H}_{2}$}

The influence of the partial pressure of $\mathrm{H}_{2}$ on reaction progression was also studied with $\mathrm{Fe}-\mathrm{Ni} / \mathrm{ZrO}_{2}$ in methanol at constant total pressure of 50 bar (Figure 4). Only a slight decrease in the yield of MP $(71-67 \%)$ was found with $10 \% \mathrm{H}_{2}$ in $\mathrm{N}_{2}\left(P_{\mathrm{H} 2}=5\right.$ bar) or with $5 \% \mathrm{H}_{2}$ in $\mathrm{N}_{2}\left(P_{\mathrm{H} 2}=2.5\right.$ bar $)$ instead of pure $\mathrm{H}_{2}$ atmosphere (73\%). Notably, even under pure $\mathrm{N}_{2}$ atmosphere without external $\mathrm{H}_{2}$ supply a MP yield of $61 \%$ was obtained (30\% without catalyst pre-reduction), clearly indicated that $\mathrm{H}_{2}$ for the reduction had evolved in situ by methanol reforming under the reaction conditions, and further demonstrating that transfer hydrogenation with methanol took place. To substantiate this rationale, reactions were performed with $\mathrm{d}_{4}$-methanol as solvent and the reaction mixtures subjected to GC-MS analysis. The resulting MS spectra revealed a major molecular ion peak at $90 \mathrm{~m} / \mathrm{z}\left(\mathrm{MP}-\mathrm{D}_{2}\right)$ as well as $91(\mathrm{M}+1)$ and $92 \mathrm{~m} / \mathrm{z}(\mathrm{M}+2)$, corroborating the decomposition of $\mathrm{CD}_{3} \mathrm{OD}$ and incorporation of $D_{2}$ into MP.

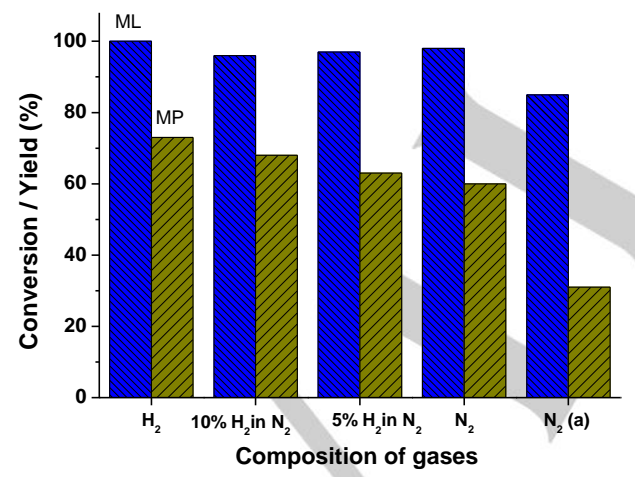

Figure 4. Influence of partial pressure of $\mathrm{H}_{2}$ on the yield of MP. Reaction condition: $2.0 \mathrm{mmol} \mathrm{ML}, 100 \mathrm{mg}$ catalyst $\left(\mathrm{Fe}-\mathrm{Ni} / \mathrm{ZrO}_{2}, \mathrm{Fe}=0.05 \mathrm{mmol}\right.$ or 2.68 wt. $\%, \mathrm{Ni}=0.025 \mathrm{mmol}$ or 1.40 wt. \%), $8 \mathrm{~g} \mathrm{MeOH}, 220{ }^{\circ} \mathrm{C}, 12 \mathrm{~h}$, total pressure 50 bar. ${ }^{a}$ Non-reduced catalyst.

\section{Influence of substrate reactivity and recyclability}

The HDO reaction with $\mathrm{Fe}-\mathrm{Ni} / \mathrm{ZrO}_{2}$ was also extended to other alkyl lactates (ALs) and the results are presented in Table 3. The reactivity towards ethyl, isopropyl and butyl lactates were almost similar to ML yielding around $70 \%$ of the corresponding alkyl propionates (APs), implying that the activity of the catalyst was unaffected by the chain length of the substrate. Moreover, in case of ethyl lactate the formation of 2-ethoxypropionate $(5 \%)$ was observed, whereas the corresponding alkoxylated byproducts with 2-propyl lactate and 1-butyl lactate did not form.

Table 3. HDO of alkyl lactates (ALs) with $\mathrm{Fe}-\mathrm{Ni} / \mathrm{ZrO}_{2}{ }^{\mathrm{a}}$

\begin{tabular}{llll}
\hline Entry & Alkyl lactate & AL Conv. (\%) & AP Yield (\%) \\
\hline 1 & Methyl lactate & $>99$ & 72 \\
2 & Ethyl lactate & $>99$ & 68 \\
3 & 2-Propyl lactate & $>99$ & 71 \\
4 & 1-Butyl lactate & $>99$ & 67
\end{tabular}

a Reaction condition: $2.0 \mathrm{mmol}$ alkyl lactate, $100 \mathrm{mg}$ catalyst $(\mathrm{Fe}=0.05 \mathrm{mmol}$ or $2.68 \mathrm{wt} \%$ and $\mathrm{Ni}=0.01 \mathrm{mmol}$ or $0.58 \mathrm{wt} \%), 8 \mathrm{~g}$ alcohol, $12 \mathrm{~h}, 220{ }^{\circ} \mathrm{C}, 50$ bar $\mathrm{H}_{2}$.

Finally, the recyclability of $\mathrm{Fe}-\mathrm{Ni} / \mathrm{ZrO}_{2}$ was evaluated by subjecting the catalyst to reuse in the $\mathrm{HDO}$ of $\mathrm{ML}$ at conditions where relatively low ML conversion was obtained (Figure 5). For the first three reactions runs, the yield of MP was unchanged around $16 \%$ whereas it increased to $22-23 \%$ for the fourth and fifth run, confirming that $\mathrm{Fe}-\mathrm{Ni} / \mathrm{ZrO}_{2}$ apparently remained stable in the consecutive reaction cycles. After the fifth reaction run the catalyst was recovered, calcined and subjected to XRD analysis. An identical diffraction pattern as for the pristine catalyst was here measured demonstrating that the material structure was intact (Figure S7). 


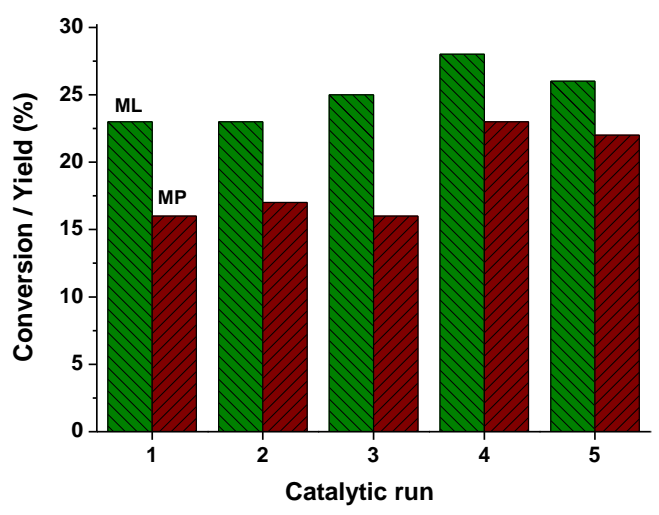

Figure 5. Recyclability of $\mathrm{Fe}-\mathrm{Ni} / \mathrm{ZrO}_{2}$ for the conversion of $\mathrm{ML}$ to MP. Reaction conditions: 2.53 wt $\%$ of $\mathrm{ML}$ in $\mathrm{MeOH}$, mass ratio of $\mathrm{ML}$ to catalyst $=2: 1(\mathrm{Fe}=$ $0.1 \mathrm{mmol}$ and $\mathrm{Ni}=0.02 \mathrm{mmol}$ with respect to $\mathrm{ML}$ ), $3 \mathrm{~h}, 220^{\circ} \mathrm{C}, 50$ bar $\mathrm{H}_{2}$.

\section{Conclusions}

The supported base-metal catalyst $\mathrm{Fe}-\mathrm{Ni} / \mathrm{ZrO}_{2}$ has beenS1 demonstrated to be a versatile, selective and efficient catalyst for $\mathrm{HDO}$ and transfer hydrogenation of alkyl lactates with molecular hydrogen and methanol, respectively, in methanol. Under optimized reaction conditions $\left(220{ }^{\circ} \mathrm{C}, 50\right.$ bar $\left.\mathrm{H}_{2}\right)$ the catalyst yielded $77 \%$ of MP from ML and about $70 \%$ products from other alkyl lactates, suggesting a general high reactivity for $\alpha$-hydroxy esters. In contrast, alternative base-metal catalysts $(\mathrm{Zn}, \mathrm{Co}, \mathrm{Ni}$, $\mathrm{Mo}$, and $\mathrm{Cu}$ ) mostly gave significantly lower catalytic activity. $\mathrm{Ni}$ synergistically promoted the catalytic $\mathrm{HDO}$ activity of $\mathrm{Fe}-\mathrm{Ni} / \mathrm{ZrO}_{2}$ to enhance the yield of MP as $\mathrm{Fe} / \mathrm{ZrO}$ and $\mathrm{Ni} / \mathrm{ZrO}_{2}$ only gave 45 and $4 \% \mathrm{MP}$, respectively (Table 1 ). This effect correlated with $\mathrm{H}_{2}$-TPR results, where $\mathrm{Fe}-\mathrm{Ni} / \mathrm{ZrO}_{2}$ exhibited lower reduction temperature than $\mathrm{Fe} / \mathrm{ZrO}{ }_{2}$ and $\mathrm{Ni} / \mathrm{ZrO}_{2}$. Moreover, $\mathrm{XRD}$ analysis revealed that doping of $\mathrm{Fe}$ and $\mathrm{Ni}$ into the $\mathrm{ZrO}_{2}$ network facilitated formation of the monoclinic $\mathrm{ZrO}_{2}$ phase, which could also be partly responsible for the improved catalytic activity of $\mathrm{Fe}-\mathrm{Ni} / \mathrm{ZrO}_{2}$ by accelerating hydrogen activation with $\mathrm{Ni}$. Intriguingly, the transformation of ML to MP in methanol with Fe$\mathrm{Ni} / \mathrm{ZrO}_{2}$ took place $(61 \%$ yield) via methanol hydrogen transfer reaction as substantiated by performing experiment under $\mathrm{N}_{2}$ atmosphere without external $\mathrm{H}_{2}$ and by a isotopic labeling experiment in deuterated methanol. Interestingly, a recyclability study showed that the activity of $\mathrm{Fe}-\mathrm{Ni} / \mathrm{ZrO}_{2}$ was maintained in at least four consecutive reaction runs, and XRD analysis confirmed the structural integrity of the spent catalyst. The developed catalyst system combines inexpensive and abundant base-metals with excellent durability, thus making its potentially attractive for conversion of other biomass-derived substrates containing hydroxyl group(s) of industrial importance.

\section{Experimental Section}

\section{Catalyst Preparation}

All the supported mono- and bimetallic catalysts were prepared by wetness impregnation by adapting the following procedure: Aqueous solution(s) of appropriate amount of respective metal(s) (Mn, Ni, Co, Cu, $\mathrm{Mo}, \mathrm{Zn}, \mathrm{Rh}, \mathrm{Ru}, \mathrm{Pd}, \mathrm{Pt}, \mathrm{Au}, \mathrm{Ag}$ or Ir) precursors were mixed with support materials $\left(\mathrm{ZrO}_{2}, \gamma-\mathrm{Al}_{2} \mathrm{O}_{3}, \mathrm{TiO}_{2}, \mathrm{SiO}_{2}\right.$, activated carbon (AC) or $\left.\mathrm{MgAl}_{2} \mathrm{O}_{4}\right)$ and the obtained slurries were thoroughly mixed for 30 mins and dried in the oven at $110{ }^{\circ} \mathrm{C}$ for $4 \mathrm{~h}$ (details on chemicals and materials in Supporting Information). The dried catalyst was then calcined at $450{ }^{\circ} \mathrm{C}$ with a ramp of $3^{\circ} \mathrm{C} / \mathrm{min}$ for $4 \mathrm{~h}$ in a static air, except activated carbon as support which instead was treated under Ar flow at a rate of $50 \mathrm{ml} / \mathrm{min}$. Commercially available $5 \mathrm{wt} . \% \mathrm{Ru} / \mathrm{AC}$ was used to prepare Ru-Re/AC catalysts by following the same procedure as mentioned above. All the catalysts were reduced at $300{ }^{\circ} \mathrm{C}$ with a ramp of $3{ }^{\circ} \mathrm{C} / \mathrm{min}$ for $3 \mathrm{~h}$ with a flow of formier gas (10 vol.\% $\mathrm{H}_{2}$ in $\mathrm{N}_{2}, 50 \mathrm{ml} / \mathrm{min}$ ) prior to catalytic test, unless otherwise mentioned.

\section{Catalyst Characterization}

$\mathrm{H}_{2}$-temperature programmed reduction (TPR) studies were performed on a Micrometrics Autochem-II instrument. In a typical procedure, approximately $100 \mathrm{mg}$ of the dried sample was placed in one arm of a Ushaped quartz tube sample holder on quartz wool. The sample was pretreated by flushing with 5 vol. $\% \mathrm{H}_{2}$ and balance $\mathrm{Ar}$ (Air Linde) at $50{ }^{\circ} \mathrm{C}$ for $30 \mathrm{~min}$ prior to the measurement, and then TPR analysis was carried out with a reducing mixture $(50 \mathrm{ml} / \mathrm{min})$ consisting of $5 \mathrm{vol} . \% \mathrm{H}_{2}$ in $\mathrm{Ar}$ (Air Linde) from 60 to $550{ }^{\circ} \mathrm{C}\left(10{ }^{\circ} \mathrm{C} / \mathrm{min}\right.$.). A thermal conductivity detector (TCD) was used to monitor the hydrogen concentration in the effluent stream and the $\mathrm{H}_{2}$ consumption values were calculated based on calibration experiments.

X-ray powder diffraction (XRPD) of activated catalysts were performed on a Huber G670 powder diffractometer using $\mathrm{Cu}$ Ka radiation with a $2 \theta$ range of $2-80^{\circ}$ at the rate of $0.02 \%$ sec.

Transmission electron microscopy (TEM) studies of reduced $\mathrm{Fe}-\mathrm{Ni} / \mathrm{ZrO}_{2}$ $(\mathrm{Fe} / \mathrm{Ni}$ molar ratio $=2$ ) were performed using a Tecnai T20 G2 and Titan instrument (Hillsboro, OR, USA) operated at 200 and $120 \mathrm{kV}$, respectively. The Titan was fitted with a field-emission electron source and a spherical aberration corrector on the condenser lens system. Reduced catalyst was dispersed on plain carbon-coated Cu grids (Agar Scientific, Stansted, UK) prior to analysis.

X-ray photoelectron spectra (XPS) were acquired ex-situ with a ThermoScientific system at room temperature using Al K-alpha radiation $(1484.6 \mathrm{eV})$. Sample charging effects were eliminated by correcting the observed spectra with the C1s binding energy value of $284.8 \mathrm{eV}$ of adventitious carbon. Peak integration and deconvolution were performed with the Avantage 4.87 software using "Smart" background correction. The molar concentrations of $\mathrm{Zr}, \mathrm{O}, \mathrm{Fe}$ and $\mathrm{Ni}$ were obtained using the areas of the corresponding peak in conjunction with their sensitivity factors (Zr3d: 7.04; O1s: 2.93; Fe2p: 16.42; Ni2p: 22.18). Fe2p spectra were deconvoluted using mixed Gaussian-Lorentzian ( $L$ share: $30 \%$ ) functions. Both the Fe2 $p_{3 / 2}$ and Fe2p $p_{1 / 2}$ peaks were fitted using peaks for $\mathrm{Fe}^{2+}$ and $\mathrm{Fe}^{3+}$ plus their respective shake-up peaks resulting in a total of eight peaks [18a]. The share of $\mathrm{Fe}^{3+}$ was calculated using the relative areas of the $\mathrm{Fe} 2 \mathrm{p}_{3 / 2}(\mathrm{III})$ and $\mathrm{Fe} 2 \mathrm{p}_{3 / 2}(\mathrm{II})$ peaks. Likewise, Ni oxidation states were obtained by deconvoluting the $\mathrm{Ni} 2 \mathrm{p}_{3 / 2}$ signals using four peaks representing $\mathrm{Ni}^{2+}, \mathrm{Ni}^{3+}$ and their respective shake-up peaks [18b]. 


\section{Catalytic Hydrodeoxygenation (HDO) of Alkyl Lactates}

HDO of alkyl lactates was performed in a $50 \mathrm{ml}$ stainless steel Parr reactor equipped with a pressure transducer and a temperature controller In a typical catalytic study, $2 \mathrm{mmol}$ of methyl lactate (ML), $100 \mathrm{mg}$ of reduced catalyst and $8 \mathrm{~g}$ of methanol were placed in the reactor and flushed with $\mathrm{H}_{2}$ or $\mathrm{N}_{2}$ gas three times before pressurized to 50 bar $\mathrm{H}_{2}$ or $\mathrm{N}_{2}$ or mixtures of $\mathrm{H}_{2}$ and $\mathrm{N}_{2}$. The reaction mixture was heated and stirring started $(350 \mathrm{rpm})$ after reaching a temperature $20{ }^{\circ} \mathrm{C}$ lower than the set temperature. The reaction solvent was changed from methanol to ethanol and 2-propanol and 1-butanol when changing the substrate from $\mathrm{ML}$ to ethyl lactate, 2-propyl lactate and 1-butyl lactate, respectively. After a reaction time of $12 \mathrm{~h}$, the reaction mixture was rapidly quenched by placing the reactor in ice-cold water. Naphthalene was used as an internal standard and added to the reaction mixture prior to analysis. Carbon balance was calculated by adding unconverted $\mathrm{ML}$ and yield of MP, MMP and n-propanol.

\section{Reactant and Product Analysis}

Aliquots of the reaction mixtures were subjected to GC-FID analysis using an Agilent $6890 \mathrm{~N}$ instrument with HP-5 capillary column $(30.0 \mathrm{~m} \times 320$ $\mu \mathrm{m} \times 0.25 \mu \mathrm{m})$. An Agilent $6850 \mathrm{GC}$ system coupled with an Agilent 5975C mass detector was used to identify the formed products. Conversion of $\mathrm{AL}$ and yield of alkyl propionates (APs) were calculated based on series of individual standards for ALs and APs with naphthalene as internal standard in respective alcohols.

\section{Recycle Study}

Recyclability of the $\mathrm{Fe}-\mathrm{Ni} / \mathrm{ZrO}$ catalyst was tested in five consecutive $\mathrm{HDO}$ reaction runs of $\mathrm{ML}$ to MP. The $\mathrm{Fe}-\mathrm{Ni} / \mathrm{ZrO}_{2}$ catalyst was removed by filtration from the reaction mixture after each catalytic run and dried at $110^{\circ} \mathrm{C}$ overnight. The dried catalyst was then reactivated at $450{ }^{\circ} \mathrm{C}$ for 4 $\mathrm{h}$ under static air, followed by reduction at $300{ }^{\circ} \mathrm{C}$ for $3 \mathrm{~h}$ under $\mathrm{H}_{2}$ flow rate of $50 \mathrm{ml} / \mathrm{min}$. After each run, the amount of $\mathrm{ML}$ and methanol were adjusted based on the recovered amount of $\mathrm{Fe}-\mathrm{Ni} / \mathrm{ZrO}_{2}$.

\section{Acknowledgements}

The Danish Council for Independent Research - Technology and Production Sciences (project no. 11-106979) has supported the work. S.S. gratefully thank Department of Biotechnology (Government of India) New Delhi, India for support.

Keywords: Alkyl lactate $\cdot$ base metal catalysts $•$ alkyl propionate $\cdot$ value-added chemicals $\cdot$ heterogeneous catalysis

[1] a) E. Henrich, N. Dahmen, E. Dinjus, J. Sauer, J. Chem. Ing. Tech. 2015, 87, 1667; (b) United Nations Department of Economic and Social Affairs Population Division, Word Population Prospects, 2015; (c) The Limits of Growth (Eds: D. H. Meadows, D. L. Meadows, J. Randers, W. W. Behrens III), Universe, New York 1972.

[2] a) A. Corma, S. Iborra, A. Velty, Chem. Rev. 2007, 107, 2411; b) H. Li, J. He, A. Riisager, S. Saravanamurugan, B. Song, S. Yang, S. ACS
Catal. 2016, 6, 7722; c) Y. Nakagawa, M. Tamura, K. Tomishige, ACS Catal. 2013, 3, 2655; d) Z. Zhang, K. Deng, ACS Catal. 2015, 5, 6529.

[3] a) T. Ennaert, J. V. Aelst, J. Dijkmans, R. D. Clercq, W. Schutyser, M. Dusselier, D. Verboekend, B. F. Sels, Chem. Soc. Rev. 2016, 45, 584 b) I. Delidovich, P. J. C. Hausoul, L. Deng, R. Pfützenreuter, M. Rose, R. Palkovits, Chem. Rev. 2016, 116, 1540.

[4] a) S. M. Coman, M. Verziu, A. Tirsoaga, B. Jurca, C. Teodorescu, V. Kuncser, V. I. Parvulescu, G. Scholz, E. Kemnitz, ACS Catal. 2015, 5, 3013; b) Y. Wang, W. Deng, B. Wang, Q. Zhang, X. Wan, Z. Tang, Y. Wang, C. Zhu, Z. Cao, G. Wang, H. Wan, Nat. Commun. 2013, 4, 2141; c) S. Saravanamurugan, A. Riisager, ChemCatChem 2013, 5, 1754.

[5] a) Y. Takeda, T. Shoji, H. Watanabe, M. Tamura, Y. Nakagawa, K. Okumura, K. Tomishige, ChemSusChem 2015, 8, 1170; b) Y. Nakagawa, K. Takada, M. Tamura, K. Tomishige, K. ACS Catal. 2014, 4, 2718; c) Z. Gui, W. Cao, S. Saravanamurugan, A. Riisager, A. L. Chen, Z. Qi, ChemCatChem 2016, 8, 3636

[6] a) D. Garlotta, J. Polym. Environ. 2001, 9, 63; b) R. P. John, K. M. Nampoothiri, A. Pandey, Appl. Microbiol. Biotechnol. 2007, 74, 524; c) M. S. Holm, S. Saravanamurugan, E. Taarning, Science, 2013, 328, 602; d) E. Taarning, S. Saravanamurugan, M. S. Holm, J. Xiong, J. R. M. West, C. H. Christensen, ChemSusChem 2009, 2, 625

[7] a) A. H. Tullo, Chem. Eng. News, 2009, 87, 22; b) B. Harris, Ingenia, 2010, 45, 18.

[8] A.M. Ruppert, K. Weinberg, R. Palkovits, Angew. Chem. Int. Ed. 2012 $51,2564-2601$.

[9] a) J. Chaminand, L. Djakovitch, P. Gallezot, P. Marion, C. Pinel, C. Rosier, Green Chem. 2004, 6, 359; b) J. Feng, H. Fu, J. Wang, R. Li, H. Chen, X. Li, Catal. Commun. 2008, 9, 1458; c) L. Kasehagen, US 3,396,199, 1968; d) U. Saxena, N. Dwivedi, S. R. Vidyarthi, Ind. Eng. Chem. Res. 2005, 44, 1466; e) F. Conradin, G. Bertossa, J. Giesen, US 2,852,570, 1958; f) I. T. Clark, J. Ind. Eng. Chem. 1958, 50, 1125.

[10] a) Z. Zhang, J. E. Jackson, D. J. Miller, Appl. Catal. A: Gen. 2001, 219, 89-98; b) T. S. Dalavoy, J. E. Jackson, G. M. Swaina, D. J. Miller J. Li, J. Lipkowski, J. Catal. 2007, 246, 15-28; c) G. Luo, S. Yan, M. Qiao, J. Zhuang, K. Fan, Appl. Catal. A: Gen. 2004, 275, 95-102; d) G. Luo, S. Yan, M. Qiao, K. Fan, J. Mol. Catal. A: Chem. 2005, 230, 69-77; e) R.D. Cortright, M. Sanchez-Castillo, J.A. Dumesic, Appl. Catal. B: Environ. 2002, 39, 353-359.

[11] J. Xue, F. Cui, Z. Huang, J. Zuo J. Chen, C. Xia, Chin. J. Catal. 2012, 33, 1642-1649.

[12] a) S. Sitthisa, W. An, D. E. Resasco, J. Catal. 2011, 284, 90-101; b) L. Yu, L. He, J. Chen, J. Zheng, L. Ye, H. Lin, Y. Yuan, ChemCatChem 2015, 7, 1701-1707: c) J. van de Loosdrecht, A.J. van Dillen, A. A. van der Horst, A. M. van der Kraan, J. W. Geus, Top. Catal. 1995, 2, 29-43; d) Y. Zhao, W. Li, M. Zhang, K. Tao, Catal. Commun. 2002, 3, 239-245; e) K. Tanabe, Mater. Chem. Phys. 1985, 13, 347-364; f) A. Methivier, M. Pijolat, J. Catal. 1993, 139, 329-337; g) P. D. L. Mercera, J. G. van Ommen, E. B. M. Doesburg, A. J. Burggraaf, J. R. H. Ross, Appl. Catal. 1991, 71, 363.

[13] a) A. Torres, D. Roy, B. Subramaniam, R. V. Chaudhari, Ind. Eng. Chem. Res. 2010, 49, 10826; b) L. Ma, D. He, Catal. Today 2010, 149 148; c) L. Ma, D. He, Top. Catal. 2009, 52, 834; d) D. D. Falcone, J. H. Hack, A. Y. Klyushin, A. Knop-Gericke, R. Schlögl, R. Davis, ACS Catal. 2015, 5, 5679

[14] a) Y.-Q. Song, H.-M. Liu, D.-H. He, Energy Fuels 2010, 24, 2817; b) A. Srivastava, M. K. Dongare, Mater. Lett. 1987, 5, 111; c) F. Maglia, U. Anselmi-Tamburini, G. Spinolo, Z. A. Munir, J. Mater. Synth. Proces. 1999, 5, 327; d) W. Stichert, F. Schuth, Chem. Mater., 1998, 10, 2020.

[15] a) F. Wyrwalski, I. F. lamonier, S. Siffert, E. A. Zhilinskaya, J. Mater. Sci., 2005, 40, 933-942; b) J. Wiwattanapongpan, O. 
WILEY-VCH

\section{FULL PAPER}

Mekasuwandumrong, C. Chaisuk, P. Praserthdam, Ceram. Int., 2007, 33, 1469-1473.

[16] a) T. Otiti; G. Ekosse, S. T. Stephen, J. Appl. Sci. Environ. Manage. 2007, 11, 57-60; b) H. Wang, Y. Fang, Y. Liu, X. Bai, J. Nat. Gas Chem. 2012, 21, 745-752; C) F. Jiao, A. Harrison, J-C. Jumas, A. V. Chadwick, W. Kockelmann, P. G. Bruce, J. Am. Chem. Soc. 2006, 128, 5468-5474; d) J. W. Nlemantsverdrlet, A. M. van der Kraan, W. L. van Dljk, H. S. van der Baan, J. Phys. Chem. 1980, 84, 3363-3370.

[17] C. Li, G. Xu, Y. Zhai, X. Liu, Y. Ma, Y. Zhang, Fuel 2017, 203, 23-31.

[18] a) K. O. Moura, R. J. S. Lima, A. A. Coelho, E. A. Souza-Junior, J. G. S. Duque, C. T. Meneses, Nanoscale 2014, 6, 352-357; b) K. Hemalatha, M. Jayakumar, P. Bera, A. S. Prakash, J. Mater. Chem. A 2015, 3, 20908-20912.

[19] A. M. Diskin, R. H. Cunningham, R. M. Ormerod, Catal. Today 1998, 46, 147.

[20] a) P. S. Lambrou, A. M. Efstathiou, J. Catal. 2006, 240, 182; b) G. Munteanu, L. llieva, D. Andreeva, Thermochim. Acta 1997, 291, 171.

[21] E. E. Unmuth, L. H. Schwartz, J. B. Butt, J. Catal. 1980, 61, 242-255.

[22] J. van de Loosdrecht, A.J. van Dillen, A. A. van der Horst, A. M. van der Kraan, J. W. Geus, Top. Catal. 1995, 2, $29-43$.
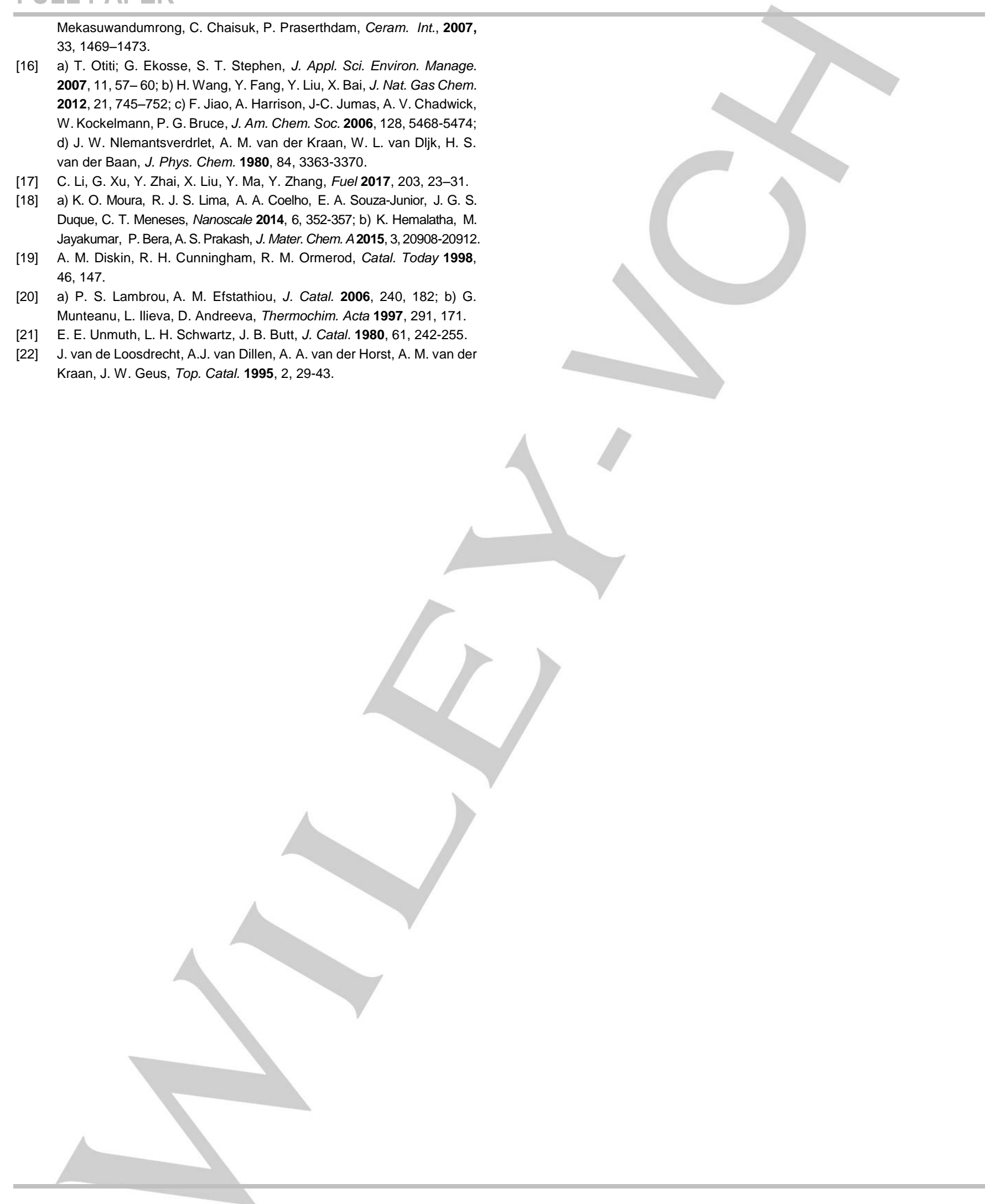


\section{Table of Contents}

\section{FULL PAPER}

Hydrogenolysis: A high yield of methyl propionate $(77 \%)$ from methyl lactate is obtained with base-metal containing catalyst $\mathrm{Fe}-\mathrm{Ni} / \mathrm{ZrO}_{2}$ in methanol in the presence of $\mathrm{H}_{2}$ atmosphere via hydrodeoxygenation and methanol hydrogen transfer reactions.

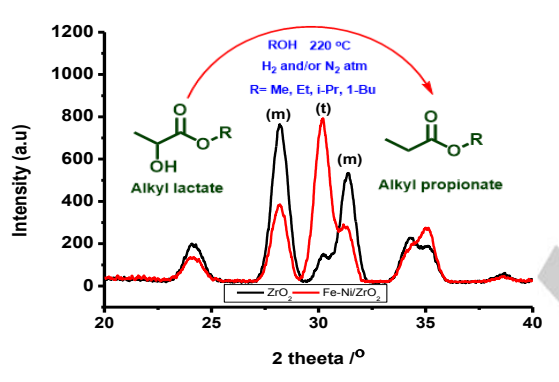

Santosh G. Khokarale, Jian He, Leonhard Schill, Song Yang, Anders Riisager, ${ }^{*}$ Shunmugavel

Saravanamurugan*

Page No. - Page No.

Selective Hydrodeoxygenation of Alkyl Lactates to Alkyl Propionates with Fe-based Bimetallic Supported Catalysts 